RESEARCH ARTICLE

\title{
'Print is Much Safer than MS': The Fate of Folklore and Folk Song Collections in the Isle of Man
}

\author{
Stephen Miller \\ Isle of Man, IM \\ chiollagh@gmail.com
}

The Isle of Man in the 1890s saw remarkable activity in the collecting of folklore and folk song, both in English and Manx Gaelic. This was followed by a further wave of collectors in the next decade, enthused by the Celtic Revival. Much of the material collected has now been lost for a variety of reasons detailed in this article. The most significant loss was that of the cylinder recordings made by the Manx Language Society between 1905 and 1913. Several collectors expressed concern in their lifetime about the survival of their papers, but this did little to prevent the loss of the collections they amassed. Such a fragmented record has consequences in researching what does now survive.

Keywords: Isle of Man; Folklore; Folk Song; Celtic Revival; Lost Collections

\section{Endangered Knowledge in the Isle of Man}

The Isle of Man-some 572 square kilometers in extent-lies in the north of the Irish Sea between Ireland and Great Britain. 55,608 inhabitants were recorded in its 1891 census, with some 30,200 then living in the island's four principal towns, predominantly Douglas, the capital. Douglas (population 19,525) was the centre of a considerable tourist industry, which attracted working class laborers from the cotton mill towns of Lancashire, but elsewhere there was economic decline. The fishing industry had collapsed, and the spring mackerel fishery at Kinsale off the southwest coast of Ireland was no longer profitable due to the rise of steam trawling in the North Sea. The ports of Peel and Port St Mary, which together once boasted the largest fishing fleet in the British Isles, now saw boats being sold for the value of their timber. Lead mining at Foxdale and Laxey was tailing off due to rising costs and falling output, with Manx miners emigrating to work the Marquette Iron Range in Michigan. Emigration to America, where a large Manx community was established in the state of Ohio as early as the 1820s, had long since depopulated the countryside, particularly in the north of the island.

The Manx language, a variant of Gaelic, was likewise in terminal decline. Its speakers had become elderly, and increasing cultural dependency on English and the imposition of Anglophone norms had resulted in no real or sustained transmission of the language to younger generations. English was now dominant, and in the 1901 census-the first to include a language question-just 4,598 people (8.4\% of the island's already fallen population of 54,752) registered themselves as having a knowledge of Manx (H. M. Government 1903: 18). ${ }^{1}$ With the passing of the language, so too would fade the vernacular culture and history that was embedded and remembered in Manx. Its extinction threatened a great deal of the communal memory of the island, which was also doomed to vanish-unless it could be captured first.

Fortunately, the 1890s saw the development of increasing interest in the island's vernacular culture, including the publication of now-classic works such as A. W. Moore's Carvalyn Gailckagh (1891), The Folklore of the Isle of Man (1891), and Manx Ballads and Music (1896), as well as Manx National Songs (1896) from brothers W. H. and J. F. Gill and Dr John Clague, followed by W. H. Gill's Manx National Songs (1898). Also active in this scene was Manchester-based folklorist Karl (later Charles) Roeder, whose principal publication, Manx Notes and Queries, would appear in 1904. The Manx Language Society (Yn Cheshaght Ghailckagh) was

\footnotetext{
1 See Table 18, 'Language Spoken.'
} 
founded in 1899, and its first President, A. W. Moore, outlined the Society's mandate as cultural preservation as well as language revitalisation:

Though called the Manx Language Society, it should, I think, by no means confine its energies to the promotion of an interest in the language, but extend them to the study of Manx history, the collection of Manx music, ballads, carols, folklore, proverbs, place-names, including the old field names which are rapidly dying out-in a word, to the preservation of everything that is distinctively Manx. (Miller 2017: 3).

While the first wave of collectors concentrated on preserving this cultural material, the second group of major collectors, active in the 1900s and led by Sophia Morrison and compatriots, sought to promote the material to a wider audience. These collectors of Manx language and culture were enthused by the Celtic Revival and the Pan-Celtic movement rather than the antiquarian impulses that drove Moore and members of the first wave. However, whatever their motivations, all the collectors of materials related to Manx language and culture working through the 1890s and early 1900s were responding to the clear need to establish a cultural record, since little of note had been collected or published until then.

This paper focuses on the six major figures involved in collecting during this period, who in turn recruited and encouraged others, thereby building a network of helpers and informants: A.W. Moore (1853-1909), Dr John Clague (1842-1908), W. H. Gill (1839-1923), J. F. Gill (1842-99), Karl Roeder (1848-1911), and Sophia Morrison (1859-1917). Moore was a member of the House of Keys, the lower elected chamber of Tynwald (the island's parliament), and the inheritor of his family's business, a rope- and sailcloth-works at Tromode, an enterprise that was declining due to the rise of steam power. He was and remains the island's foremost antiquarian and historian. Clague was a medical practitioner living in Castletown in the south of the island who collaborated with the Gill brothers-W. H. Gill, who was a civil servant in the General Post Office in London, and J. F. Gill, who held the office of High Court Judge, or Deemster, of the island-to collect folk songs throughout the island. Roeder, who knew Moore, was of Germanic origin but resided in Manchester, where he worked as a patents' and manufacturers' agent for the cotton industry. He corresponded with Moore as well as Morrison, who was independently wealthy, her father having made his money in supplying the Peel fishing fleet and wisely investing the profits in property, thus allowing the family to survive and thrive after the collapse of the fishing industry. The fate of these amateur philologists' and folklorists' personal papers and collections forms the narrative of this piece. Some further contexts for their loss are treated in the next section.

\section{'[P]rint is much safer than MS'}

The figures listed above all contended with the challenge of how best to preserve the materials they collected. 'I feel that if anything were to happen to me, print is much safer than MS': so wrote A. W. Moore to Karl Roeder in $1893 .{ }^{2}$ He had recently learnt that a hoped-for second edition of The Folk-lore of the Isle of Man was to be cancelled due to low sales, and that stock of the first edition remained available for sale. He sought then to publish his supplementary material elsewhere, in order to safeguard it. A decade later, Sophia Morrison faced a different dilemma: the possibility that publishing content might actually preclude her from gaining further access to material in order to preserve it. She received a letter in 1903 from William Boyd-Hawkins, who wrote of being 'fascinated by the lore of the Island, which I hope you will not allow to pass away without record. All the fragments should be collected so that nothing be lost. You can do this quietly in Peel-without publishing for the present-I fear, that, if you publish, the old people will not tell you anything!'3 This fear was not unfounded; the previous year, Karl Roeder had apologised in his Manx Notes and Queries column in the Isle of Man Examiner as "[i]t appears that my recent note, No. 79, on "Malicious Spirit," and previous matter, has greatly vexed some of the good people in Cregneash whom I much esteem' (Roeder 1902). In other words, the 'folk' were now reading what folklorists were writing about them and were displeased with what they saw.

Furthermore, the island had witnessed a number of Methodist religious revivals in the second half of the nineteenth century, whose influence was leading to a willing displacement of vernacular culture in the ethnographic record. Sophia Morrison encountered these attitudes first-hand when collecting audiorecordings with the phonograph, as she reported in 1905:

\footnotetext{
2 Letter from A.W. Moore to Karl Roeder, 30 November 1893, M277/12/1-65, Manchester City Archives.

3 Letter from William Boyd-Hawkins to Sophia Morrison, 15 August 1903, MS 09495, box 1.
} 
One difficulty in the way of obtaining the material which we want, has been, as I have found by experience, the unwillingness of our intensely earnest and religious peasantry to speak into the instrument such 'boghtynid' [Manx, lit., 'rubbish'] as folk-stories and sayings and secular songs. They prefer that such a serious thing as a record which is to be handed down to posterity shall consist of Hymns, Scripture, or Carvals. (Morrison 1905: 4).

Finally, preservation was sometimes impeded by limitations of time and labour on the part of the collectors. 'During this last month, I have collected 6 or 7 note books full of Charms \& herbal remedies,' wrote Morrison to Roeder in an undated letter. ${ }^{4}$ Similarly, in another letter to Roeder, she wrote, 'I send you my notes on Charms \& Charmers, Manx Dye Plants \& Herbal Remedies. I collected them about four years ago \& have added nothing to them since,' going on to add that she had 'always intended to work them up, but from lack of time [had] not done so. ${ }^{5}$ These notes are not to be found amongst her personal papers now housed in the Manx National Heritage Library (MNHL), nor, for that matter, in what little remains of Roeder's own papers in the Manchester Central Library. It is only references such as these that now indicate the scale and pace of collecting and hint at the types of material lost from sight. This second letter affords additional insight into why collected cultural material might remain in 'unsafe' manuscript form: where, for instance, Moore faced a tepid booksellers' market, Morrison sometimes lacked time or space in which to write her notes up for publication.

\section{A.W. Moore (1853-1909): "Manx "Odds \& Ends"'}

Alongside his numerous other smaller publications, Moore's two-volume A History of the Isle of Man appeared in 1900. But his worries about the safety of his personal papers, expressed in the letter to Roeder cited above, were proven to be justified, as little now remains of his manuscript works. All that now survives of his unpublished antiquarian (and other) ${ }^{6}$ endeavours is a single notebook, somewhat appropriately titled Manx 'Odds \& Ends' (MNHL, MS $221 \mathrm{~A}$ ), along with some proof-sheets of the tunes that appeared in Manx Ballads and Music (MNHL, J48-13XF). Moore had also acquired the folklore and folk song collection of Robert Gawne, who was active as a collector in the 1830s but of whom no other biographical details are known. This collection was published only in part, omitting erotic or bawdy texts-though Moore at one time did intend to publish them, as can be seen in an 1896 letter to him from T. E. Brown, the author of the book's preface: 'I have none of the Love songs (indecent), which I think you intend publishing in Manx only." These, too, never appeared and are now known only through a footnote listing their titles in Manx Ballads and Music.

\section{Dr John Clague (1842-1908): '6 or 7 tons of books \& papers'}

'We had to take to our house, as far as I can judge, 6 or 7 tons of books \& papers, \& our house is only a small one,' wrote the Reverend John Kewley to Sophia Morrison in 1911. ${ }^{8}$ This was the size of the personal library and papers collection of Dr John Clague, which passed to Kewley, his close friend, upon the death of his widow Margaret Clague in 1911. Clague published nothing in his lifetime, though material from his collaboration with the Gill brothers appeared in Manx National Songs (1896) and Manx National Music (1898). A lost project, Manx National Airs, which he edited with J. F. Gill, came to light only with the release of the Deemster Gill Papers by the Manx National Heritage Library in 2000; the manuscript, however, is missing. The product of Clague's folk song collecting was contained in a set of four tune books. These contain some 315 tunes (also incorporating those collected by the Gill brothers) and is the most substantial manuscript record of Manx folk song.

A copy of the Clague Collection was made by Edmund Goodwin for Sophia Morrison in 1913, and a number of the tunes appeared in the small-press magazine she edited and at times self-financed, Mannin. Morrison floated proposals to publish selections from the Clague Collection, but these aspirations came

\footnotetext{
${ }^{4}$ Copy letter (fragment) from Sophia Morrison to Karl Roeder, undated, MS 09495, box 5.

5 Copy letter of Sophia Morrison to Karl Roeder, undated [April? 1906], MS 09495, Letter Copybook (1904-07), box 4.

${ }^{6}$ For his folklore and folk song publications, see Miller (1993). Not only was Moore interested in folklore and folk song, he was also a leading politician. From 1989 to 1909, he was the Speaker of the House of Keys (the lower elected house of Tynwald, the island's parliament), at a time of confrontation with Lord Raglan, its autocractic Lieutenant-Governor.

7 Letter from T. E. Brown to A. W. Moore, 19 February 1896, MS 1277/50 A.

${ }^{8}$ Letter from Rev. John Kewley to Sophia Morrison, 1 May 1911, MS 09495, box 3. He wrote the following month to G. W. Wood, the noted Manx bibliophile, that 'I have not yet been able to get the books into order, as I am short of shelving, \& of room for the shelves. I had a fairly large collection of my own to start with, and now that a second lot has come, I find great difficulty in finding room for them as this is only a small house' (Letter from Rev. John Kewley to G. W. Wood, 30 June 1911, MS 1185/2 A.).
} 
to nothing-they did generate other transcripts in the process, but these too are all now lost. Goodwin produced two transcripts for Morrison, along with an index to the collection. Both transcripts are nowhere to be found amongst her papers; the index, however, is now in the MNHL. The originals of Goodwin's working transcripts of the Clague Collection, photocopies of which are held by the MNHL, have recently been located in private hands.

'I shall love to avail myself of your delightful offer to lend me Dr Clague's MS. collection. It is most kind, and I will take every care of the books while in possession [of them.]' ${ }^{\prime 9}$ Thus wrote A. G. Gilchrist in 1916, who was to aid Morrison in selecting tunes for Mannin and would go on edit a substantial portion of the tune books published the Journal of the Folk-Song Society between 1924-26, ${ }^{10}$ using the originals held by Kewley. Gilchrist's editing of the Clague material was to lead to the recovery of more material relating to folk song from amongst the man's personal papers: 'Since Part i appeared in Journal No. 28, a fortunate chance has led to the discovery of more Clague mss' (Broadwood 1925: v). These were duly edited and returned and so now are lost along with the rest of Clague's ' 6 or 7 tons of books \& papers,' with the exception of the seemingly chance deposit of four tunes books, as the Journal of the Manx Museum reported in 1935:

These books were bequeathed by his widow to his intimate friend, the Ven. Archdeacon Kewley, who, being confident that it would be in accordance with the Doctor's wishes, handed them over to Mr J.E. Quayle, B.Mus., who, having examined them very closely, says that while not all these tunes are Manx in their origin-many being so only by association-they do form the foundation upon which practically all later activities in the field rest. (Cubbon 1935).

These are now recorded as MNHL, MS 448/1-3 A and MS 449 B. There was also, that same year, a deposit by Kewley of twenty-four notebooks in Clague's hand (MNHL, MS 450/1-24 A).

Kewley retired from the Rectory at Kirk Andreas in 1938, where he had resided with his two unmarried sisters since taking on the living there when he was appointed as Archdeacon in 1912, and he died in 1941. His sisters went to live in Castletown and had part of Clague's library in their possession. C. I. Paton looked it over in 1942, making multiple notes about it in his diary: 'After tea to the Kewley's, looking through their books. They are too kind in wanting me to take any that I have not got \& in wanting the Museum to have them' (29 May 1942); '[a]ll my after tea time-about 5.15 to 8.30 looking over books etc. at the Kewley's' (5 June 1942); '[f]inished checking the Kewley's books for the Museum \& took away various books wh. they insisted on giving me-including some rare pieces' (9 June 1942); and '[m] useum-met Mr Megaw. Took the Kewley's books there' (11 June 1942). ${ }^{11}$ Paton makes no mention at all of manuscripts, yet he knew full well that Kewley had possessed manuscript material because he had worked alongside him on Gilchrist's edition of a selection of tunes from the Clague Collection. Paton had, in fact, even worked on some of the song texts produced by Kewley from amongst Clague's papers. ${ }^{12}$ The reason for this omission is unclear. What remains clear, however, is that since the deposit of the Clague material in 1935, nothing more has surfaced.

\section{W. H. Gill (1839-1923): 'My Papers: What shall I do with them?'}

In his later years, W. H. Gill took to producing letters titled 'Leaves from my Spiritual Diary.' Gill sent one such letter to Morrison in 1915, the topic of which was 'My Papers:|What shall I do with them?,' that demonstrates his preoccupation with the eventual custodianship of his archives. ${ }^{13}$ In fact, Gill first began to contemplate the fate of his papers in 1911, as shown here in a letter from Morrison dated 22 January 1911:

Thank you too for the honour you do me in asking me in the event of my surviving you-which I must remind you is only a possible, not by any means a certain contingency-to look after your

\footnotetext{
${ }^{9}$ Letter (fragment) from [A. G. Gilchrist] to Sophia Morrison, 20 January 1916, MS 09495, box 5.

${ }^{10}$ A. G. Gilchrist, 'Songs from the Isle of Man (Part i),' Journal of the Folk-Song Society vii.28 (1924), A. G. Gilchrist, 'Songs from the Isle of Man (Part ii),' Journal of the Folk-Song Society vii.29 (1925), A. G. Gilchrist, 'Songs from the Isle of Man (Part iii),' Journal of the Folk-Song Society vii.30 (1926).

11 C. I. Paton personal diary (1905-49), in family hands.

${ }^{12}$ Further from Paton's diary: 'Heard from Kewley sending verses from Dr Clague's collection' (27 May 1925); 'Corrected the above' (28 May 1925); 'I finished correcting above \& sent them on to Miss Gilchrist' (29 May 1925).

${ }^{13}$ Letter ('Leaves from my Spiritual Diary') from W. H. Gill, 28 March 1915 [but composed several years earlier], now in the archives of Sophia Morrison, MS 09495, box 2. Likely written in 1913.
} 
Manx Music \& papers. I doubt my power to undertake. Before I can answer definitely yes or no you must tell me exactly what you would wish me to do so. ${ }^{14}$

Perhaps at this point Gill was unsure what he wanted to do with his papers, but by March 1913 he was hard at work on organising his archive, as a letter to Morrison indicates: 'For the past three weeks and all day long I have been trying to get Order out of Chaos as regards my papers and it will take another perhaps still longer period before my "Index Rerum" or Inventory is complete.' His first priority, as he continued in the letter, was to deal with the material on Manx folk song he had assembled together with his brother and Dr John Clague: 'My first object has been to get together every existing scrap relating to Manx Music in general and out of this mass to sort out every item relating to the joint work of my Brother, Dr Clague, and myself.' Time was of the essence, for ' [n]ow my days are numbered I can but give an account of my stewardship if only to save others from doing over-again work which has already been done however imperfectly by myself.' In fact, Gill was to live almost another decade after this letter, but the urgency he felt at the time apparently compelled him to set some priorities for preservation. In the same letter, he mentions for the first time what he was considering depositing and, equally importantly, where: 'I think the book of Melodies and a selection from the Correspondence should be deposited in your Public Library,' a reference to the Douglas Borough Public Library. ${ }^{15}$ He was still hard at work the next month of April, when he wrote to Morrison again:

For six weeks, all day long, I have been excavating every hole and corner of my work-room dredging and sorting and indexing every single paper so that I can now lay my hand upon the file or bundle and also on any individual paper therein. But oh the heaps upon heaps! ${ }^{16}$

However, Gill was now ready to deposit his material: 'Unless you have any objection I have ready for sending to you all the correspondence between $\mathrm{D}^{\mathrm{r}}$ Clague, my Brother, and Mess ${ }^{\text {rs }}$ Boosey.' He was also aware that there should be material from Deemster Gill in the hands of his widow. 'If this should prove to be incomplete, there may possibly be other documents on the subject which $\mathrm{M}^{\mathrm{rs}} \mathrm{J}$.F. Gill says are in the keeping of $\mathrm{D}^{\mathrm{r}}$ Mackenzie (in a locked drawer) but she thinks this is highly improbable. ${ }^{17}$ His letters to Morrison indicate that he was seriously considering the fate of his archives and was taking steps to ensure their preservation. Yet, in the end, Gill never delivered his papers to the Douglas Public Library. His correspondence with Morrison (which was extensive and seems to remain largely intact amongst her papers) becomes silent on the point of his own papers after 1913.

The loss of these materials is difficult to understand, especially given Gill's concern that his papers be preserved, and his efforts at preparation of that archive in a systematic manner. In his many years of retirement, Gill chose to live with his wife and their unmarried daughters, Florence and Margaret, in 'The White House,' in the village of Angmering in West Sussex, and he lived on another decade there after this last burst of letters to Morrison. Morrison herself, the original intended recipient of his personal collection, died in 1917. Gill had earlier contemplated leaving to the British Museum Library some form of transcript of the field collection made with his brother but ultimately did not deposit any material there either. Gill's daughters were still living in 'The White House' in 1936, as in that year Florence donated a photograph of her father to the Manx Museum Library. ${ }^{18}$ Florence died in 1948, and her sister Margaret the following year. Whatever Gill's concerns were for his papers, it would seem that his daughters did not share them, and so we are left with just a single photograph.

\section{Deemster J. F. Gill (1842-99): 'Letters can do so little'}

John Frederick Gill lived in the Isle of Man and was appointed, in his later years, to the Manx judiciary as a Deemster; meanwhile, his brother, W. H. Gill, lived in the Home Counties and worked as a senior civil servant in the headquarters of the General Post Office in London. As J. F. Gill wrote in October 1894 to his brother, '[o] ur separation places us all at a disadvantage-More could be done in a single interview than by 20 letters.' ${ }^{19}$ 'Yes, a talk would do so much; while letters can do so little,' replied W. H. Gill in May of the following year. ${ }^{20}$

\footnotetext{
${ }^{14}$ Copy letter of Sophia Morrison to W. H. Gill, 22 January 1911, MS 09495, (Small) Letter copy book (1908-13), box 4.

${ }_{15}$ Quoted throughout: letter from W. H. Gill to Sophia Morrison, 27 March 1913, MS 09495, box 2.

${ }^{16}$ Letter from W. H. Gill to Sophia Morrison, 10 April 1913, MS 09495, box 2.

${ }_{17}$ Letter from W. H. Gill to Sophia Morrison, 10 April 1913, MS 09495, box 2.

${ }_{18}$ Photographic Archive, File Persons Gill I, MNHL. Donated by Miss Florence E. Gill, annotated with the date 8 August 1935.

19 Letter from Deemster J. F. Gill to W. H. Gill, 29 October 1894, MS 09702, box 2, MNHL.

20 Letter from W. H. Gill to Deemster J. F. Gill, 25 May 1895, MS 09702, box 2.
} 
Geographical separation meant that they had to write to each other to discuss both their plans for collecting folk songs and the editing of what was to become Manx National Songs (1896). The collecting abilities of the Gill brothers were the subject of a poison pen portrait in 1937, in which J. E. Quayle wrote:

Deemster's Gill's part in the matter, was, I think, negligible. It was not given him to 'unlock the treasure of the Island heart.' Different in almost every way to his brother, he combined with an austere and somewhat solemn aspect, an aloofness of manner which invited no confidences, and opened no closed doors (Quayle 1937: 240-41).

Quayle comprehensively dismissed the pair as having done nothing original and nothing off their own bat, a view shared by many.

That we now know a different state of affairs is due to the MNHL's autumn 2000 release of the personal papers of Deemster Gill. This deposit consists of material sufficient in extent to fill two large archival boxes, the first containing various miscellaneous family papers and the second containing materials relating to the folk song collecting activities of the Deemster and his brother. The papers in the second box broadly consist of: (i) a bound transcript of 101 tunes collected in the field by W. H. Gill, accompanied by his brother, in 1895 and 1898; (ii) forty-eight letters between the brothers, dating between 1894 and 1898, concerning the editing and production of Manx National Songs (1896) and (less so) Manx National Music (1898), together with a number of enclosures; (iii) fourteen letters from Dr John Clague, their collaborator; (iv) thirteen letters to Deemster J. F. Gill from various correspondents, who formed his circle of helpers in the search for singers; and (v) various field and interview notes, song texts from helpers, and similar material passed on by Clague. The irony here is that the Gill brothers, hitherto marginalised figures, have now left more material for study than any of the other folk song collectors active in this and later periods. This provides the only true success story of a robust collection from the period coming to light.

\section{Karl Roeder (1848-1911): 'It was a staggering blow in many senses'}

'It was a staggering blow in many senses,' wrote Karl Roeder in a 1908 letter to Sophia Morrison about the loss of his personal papers. He recounted the circumstances:

As I said, I had collected a multitude of material for that purpose, but since my long last illness, 3 years ago, when all my things were removed $\&$ packed away $\&$ stored, many of my books, $\&$ notes were lost $\&$ dispersed, by bad management of the wretched removers, $\&$ are irrecoverably gone, also with [other] valuable papers, maps, plans $\&$ what not. ${ }^{21}$

Some material did remain in his own hands. Part of it was later deposited in the Manchester City Library in the form of a scrapbook containing, inter alia, letters from Morrison, A. W. Moore, and Edward Faragher of Cregneash, his village informant and the figure who had occasioned Roeder's letter of apology to the Manx press in 1902.

Roeder resided in Manchester, where one of Morrison's brothers, for whom she often acted as housekeeper, practised medicine. In an undated letter to J. J. Kneen, another of the stalwarts of the Celtic Revival in the Isle of Man, Sophia Morrison mentioned having 'called on Miss Roeder [Roeder's sister] \& she has given me a fat packet of Manx scraps-Faragher's of Cregneish letters to her brother, also four of F. Note Books, \& letters from Hudson (weaver) Surby-letters of yours-two-\& many others. ${ }^{22}$ Morrison circulated this material privately, and many of the letters from Faragher to Roeder remained in the hands of members of her circle after her death in 1917. A small quantity has come to be deposited in the Manx Museum Library (now the Manx National Heritage Library) over the years, and now spans some ten manuscript numbers. It is clear that material has been lost, as copies of a number of Roeder's manuscripts, in his own hand, lie amongst Edmund Goodwin's papers. ${ }^{23}$

${ }^{21}$ Letter from Karl Roeder to Sophia Morrison, MS 09495, box 6.

${ }^{22}$ Letter from Sophia Morrison to J. J. Kneen, [undated], MS 1513 (d) B.

${ }^{23}$ Goodwin was, incidentally, a cousin of Morrison's. Two manuscript copies in Goodwin's hand were held by private collectors until recently purchased by the MNHL. Remarkably, I myself came across manuscripts from this 'fat packet' in the Douglas Public Library-an institution that was not thought to have any manuscript holdings at all-in 1981, as a result of a casual enquiry. Curiously, they had been left there despite former librarian William Cubbon going on to join the newly established Manx Museum in 1922 and thereafter building up its collections of manuscripts and printed material. 


\section{Sophia Morrison (1859-1917): 'A new ally has come to the cause'}

'A new ally has come to the cause in the form of an Edison Phonograph, whose function it is to preserve the Manx sounds as uttered by native speakers' (Morrison 1905: 4). ${ }^{24}$ So wrote Sophia Morrison, Secretary of the Manx Language Society, in her annual report for 1905. The Society's balance sheet outlined expenditures on this new found ally: $£ 715 s 0 d$ for the phonograph itself, complete with an extra horn, stand, and basket; $£ 1$ $16 s$ od on blank wax cylinders; and the sum of 12/- for repairs to the phonograph itself, perhaps damaged in transit to the island (Yn Cheshaght Ghailckagh 1905). The Society set to work at once, with the first report of the 'new ally' appearing in the Peel City Guardian on 15 April 1905.

In December 1896, the Hungarian musician and folk song collector Béla Vikár became the first person in Europe to record traditional music with the phonograph, which he employed because of his inability to notate music (Kovács 1993: 52). Much later, P. W. Caine, one of Morrison's circle of collectors and helpers, conveyed the difficulty of notating in the field, in a 1914 letter to her, commenting that ' $[\mathrm{t}$ ]aking down music in the Dorian mode is not so easy as it looks, \& one is apt to lose the key, especially when the singer's voice has lost some of its pristine freshness.' ${ }^{25}$ The taxing nature of transcription placed a limit on the amount of material that could be comfortably gathered in one session, ${ }^{26}$ and the phonograph, at first, appeared to be able to remove such constraints with the literal drop of a needle. In 1907, Charles Myres wrote a paper titled 'The Ethnological Study of Music.' Its appendix, 'The Manipulation of the Phonograph,' described the kit and accessories that comprised the Edison Standard phonograph and spelt out in detail the ways the phonograph might be used in the field for recording traditional music. ${ }^{27}$ The new technology seemed like it would revolutionise field research by facilitating the preservation of sound.

If anything, however, recording with the phonograph proved to be less 'spontaneous' than collecting with paper and pen, and the material was more difficult to organise. For example, a rehearsal was advisable before recording began, and the output of a session might vary from singer to singer because of variations in their individual voice quality. Further, Myers advised, 'the title of the song should be sung into the phonograph before the record is taken. This is to be followed by the sounding of the pitch-pipe, which should serve as a signal for the musicians to begin' (Myers 1907: 252). Another physical constraint was the running time of the cylinder itself, which varied between two and three and a half minutes long and made the recording of any but the shortest pieces difficult.

A short, unfortunately undated, account by Morrison survives of her experiences collecting with the phonograph. Coming across a Manx emigrant who was returning for the last time on a visit from Arizona, she discovered he was the son of 'Tom Billy Hal' (Thomas Callister), to whom 'Arrane ny Ferrishyn Ghelbee' ('Song of the Dalby Fairies') was attributed. In 'Manx Fragments of Music,' housed in Morrison's papers at the MNHL, she describes the encounter: 'I invited him to my house and asked him to sing some of his father's songs into the M. L. S. gramophone. ${ }^{28}$ The manuscript then sadly breaks off, but not before mentioning that Callister was nervous at the idea of being recorded. While this apprehension was also a feature of collecting with pen and paper, the physical presence of the phonograph exacerbated the anxiety of the singer or informant. John Nelson, one of the helpers recruited by Morrison, had a similar experience when collecting recited material, writing when sending a box of cylinders to William Cubbon in 1906 that 'there are a few little Stammers \& repetition here $\&$ there which is very hard to avoid as you have to Keep going like a water wheel when you once start.'29

\footnotetext{
${ }^{24}$ For a history of the phonograph, see George List, 'A Short History of the Cylinder Phonograph [Part 1],' The Folklore and Folk Music Archivist i.2 1958a). George List, 'A Short History of the Cylinder Phonograph [Part 2],' The Folklore and Folk Music Archivist i.3 1958b). The early history of recording with the phonograph is discussed in Alexander Rehding, 'Wax Cylinder Revolutions,' The Musical Quarterly 88.1 (2005). See too, Erika Brady, A Spiral Way: How the Phonograph Changed Ethnography (Jackson: University Press of Mississippi, 1999). The extant sound recordings of Manx Gaelic are detailed in George [as 'Shorys y Creayrie'] Broderick, ‘Recording Native Manx Speech,' For a Celtic Future: A Tribute to Alan Heusaff, ed. Cathal Ó Luain (Dublin: The Celtic League, n.d. [but 1983]).

25 Letter from P. W. Caine to Sophia Morrison, 24 February 1914, MS 09495, box 1.

${ }^{26}$ For example, recording three tunes per session seems to have been the norm for Dr John Clague. As Clague wrote to J. F. Gill on 25 December 1895, '[a]n old blind man-Tom Kermode by name, has given me three splendid old songs, and I think I shall be able to get three more yet. I have had three from old Fargher who gave me 'Shannon Rea,' and he has another which I shall probably get this week' (Letter from Dr John Clague to Deemster J. F. Gill, 25 December 1895, MS 09702, box 2).

27 See Charles S. Myers, 'The Ethnological Study of Music. Appendix: The Manipulation of the Phonograph,' Anthropological Essays presented to Edward Burnett Tylor, ed. Northcote W. Thomas (Oxford: The Clarendon Press, 1907) 249-53.

${ }^{28}$ Sophia Morrison, 'Manx Fragments of Music,' MS 09495, box 7. Various copies of folk songs in Morrison's hand are now coming to light among her papers. It is a moot point as to how many of these may be transcripts from phonograph recordings.

${ }^{29}$ Letter from John Nelson to William Cubbon, 28 November 1906, MS 5606 A.
} 
The Society's recording programme ran from 1904 until 1908 at the latest, judging from the purchasing of blank records listed in its yearly expenditures. Smaller numbers of records were bought over the years: $£ 116 \mathrm{~s}$ $0 d$ was spent initially, followed by $11 s 6 d$ in the Report for 1906 (Yn Cheshaght Ghailckagh 1906), $8 s 1 d$ in 1908 (the Report for 1907 having never appeared), and, finally, just 5s 6d in 1909 (Yn Cheshaght Ghailckagh 1909a). After the 1909 report, no further expenditure by the Society on blank records is listed, but recording activities were clearly taking place as late as 1913, with Morrison writing to Kneen in September of that year, 'I am hoping you will be able to use the M.L.S. Phonograph during the winter.' ${ }^{30}$ This statement is puzzling, and one is left to conclude that Morrison and the others must have carried on by paying for the recordings out of their own pockets. The minute books do not provide background on this discontinuation of spending, but neither is there any mention in surviving correspondence as to any difficulty individuals may have had with the Society continuing to fund the purchase of cylinders. ${ }^{31}$ Frustrating, too, is the dearth of mention of the phonograph in Morrison's annual secretarial reports, save one in 1906 (Morrison 1906: 6).

By 1925, J. J. Kneen, now Secretary of the Society, ${ }^{32}$ could comment on a proposal by the nascent Manx Museum to initiate its own sound recording programme that '[t]he Manx Society did acquire a phonograph some years ago, but as the impressions were only in wax, the records would not be of an enduring nature' (Kneen 1925: 6). In fact, it was possible to reproduce cylinders in this period with the so-called Galvano process used at the Berlin Phonogrammarchiv from 1902 onwards. ${ }^{33}$ Berlin frequently accepted cylinders from other sources to copy and thereby safeguard (Clayton 1996: 80-83). The Vienna Phonogrammarchiv also developed a mechanical system for dubbing from cylinder to disk (List 1958a: 1a).

In the annual report for 1909, A. W. Moore 'mentioned that that a very distinguished Austrian Professor paid a short visit to the Island in the spring of the year.' (Yn Cheshaght Ghailckagh 1909b: 6). This was Rudolf Trebitsch (1876-1918), a wealthy amateur ethnologist who worked in close cooperation with the Phonogrammarchiv of both Vienna and Berlin (established in 1899 and 1900 respectively). Able to finance his own travel and research, he visited first Greenland in 1906, and then from 1907-9 travelled widely in Ireland, Wales, Brittany, the Isle of Man, and Scotland. ${ }^{34}$ Trebitsch is known to have made three visits to Man, once in 1907 and twice in 1909. ${ }^{35}$ The recordings he made in 1907 are lost and there seems to be no accounting of what was recorded, but those from 1909 are to be found in the Phonogrammarchiv in Vienna. ${ }^{36}$ It is unclear why no formal link was established between the Manx Language Society and the Phonogrammarchiv and what became of recordings made during Trebitsch's 1907 visit, mentioned by the Society.

All that now survives of the recording programme of the Manx Language Society is a 1906 letter from John Nelson to William Cubbon: 'I am sending you a Box Containing 8 broken records, \& 4 cut records which has some blemish's on, and they are not to my mind satisfactory to leave for after generations to hear. ${ }^{37}$ The Reverend E. B. Savage, in his 1905 Presidential Address to the Society, spoke of the programme in these terms: 'Our phonograph will preserve the speech and accent of Manx people of this generation, from different parts of the Island' (Savage 1905: 2). The unintended irony here is that those people who recorded

30 Letter from Sophia Morrison to J. J. Kneen, 14 September 1913, MS 1086/36 C.

31 Remarkably, no minutes were recorded for the Executive or Committee meetings for 1906 through to 1908; while the minutes of both committees do exist for 1909, the last year in which the MLS are recorded as purchasing cylinders, there is no record of any debate about the continuance or abeyance of the recording program (MLS Minute Book [1899-1913], Yn Cheshaght Ghailckagh archive).

32 Morrison died in 1917 and was succeeded in post first by Mona Douglas, later by Kneen.

33 See George List, 'The Reproduction of Cylinder Recordings [Part 1],' The Folklore and Folk Music Archivist i.4 1958c): [1] col. a-[2] col. b. Further, see Martin Clayton, 'Ethnographic Wax Cylinders at the British Library National Sound Archives: A Brief History and Description of the Collection,' British Journal of Ethnomusicology 5 (1996): 80-83.

${ }^{34}$ His field recordings from the various Celtic countries have recently been released. Gerda Lechleitner and Ulla Remmer, eds., The Collections of Rudolf Trebitsch: Celtic Recordings-Ireland, Wales, Brittany, Isle of Man, and Scotland (1907-09), vol. 5/2 (Vienna: Österreichische Akademie der Wissenschaften, 2003). Incidentally, Trebitsch also mentions a difficulty with potential informants, namely their lack of teeth. Ulla Remmer, 'Rudolf Trebitsch and the Celtic Languages,' The Collections of Rudolf Trebitsch: Celtic Recordings-Ireland, Wales, Brittany, Isle of Man, and Scotland (1907-09), eds. Gerda Lechleitner and Ulla Remmer, vol. 5/2, Sound Documents from the Phonogrammarchiv of the Austrian Academy of Sciences: The Complete Historical Collections 1899-1950 (Vienna: Österreichische Akademie der Wissenschaften, 2003) 18 col. a.

35 See Remmer, 'Rudolf Trebitsch and the Celtic Languages,' 21 col. b. For Trebitsch's own report, see Rudolf Trebitsch, ‘Phonographische Aufnahmen der Welschen Sprache in Wales, der Manxschen Sprache auf der Insel Man, der Gälischen Sprache in Schottland und eines Musikinstrumentes in Schottland,' Anzeiger der Kaiserlichen Akademie der Wissenschaften (Philosophisch-Historische Klasse) xlvi (1909): 170.

36 Austrian Academy of Sciences, Phonogrammarchiv, Ph. 1072, 1088-96. Available on OEAW PHA CD 14/2, tracks 11-20.

37 The quality of the cylinders was the problem, and the Society had also neglected to purchase a cleaner. See the letter from John Nelson to William Cubbon, 28 November 1906, MS 5606 A. 
with the 'new ally' outlived the cylinders themselves. The phonographic device survives as well, a mute testament to what is a remarkable episode in the early collecting and recording of Manx. ${ }^{38}$

\section{Endnote: 'The Last Minstels' and the Archive}

'The Last Minstrels' was W. H. Gill's term for the folk singers he and his brother found in the 1890s. It can be taken as a kind of shorthand for the attitude of finality each of these collectors held in that decade-namely, that they were collecting from the last singer and the last speaker of a soon-to-vanish Manx vernacular culture. It was an attitude continued by the collectors that would follow them; Sophia Morrison's protégé Mona Douglas (1898-1987), for example, wrote to her mentor in 1916 that 'I have very little fresh in the way of folklore. Just a few broken bits of stories. ${ }^{39}$ Her letter describes a fragmented record that suggests the precariousness of the culture as a whole. The material found was also described as scraps and fragments, and the paradigm adopted was later described as salvage ethnography or, in the words of Jacob Gruber, a collection of data rather than a body of data' (Gruber 1970: $1297 \mathrm{col}$. b). That they were in one sense content to collect so little-influenced by the notion that it was already too late to capture it all-contributed to some (but not all) Manx linguistic and ethnographic collections being small in size and so vulnerable to loss.

A. W. Moore trusted print to preserve his collecting; Sophia Morrison looked to the phonograph to capture orality; and W. H. Gill hoped that Morrison would take over custodianship of his papers. Morrison's own papers remained in family hands until they were deposited in the Manx Museum Library in 1958, though by then clearly a substantial portion had been lost. Karl Roeder's papers went missing in his own lifetime; those of Dr John Clague suffered the same fate much later. Deemster J. F. Gill's papers have surfaced, to great surprise because no one had thought they existed in the first place. And legibility is a problem in the surviving pencilled manuscripts of Clague and Deemster Gill; in many places one has difficulty figuring out just what the smudged handwriting originally read. The remains of these collections are now the archival record of a vernacular culture that was indeed to pass, though not as rapidly as was feared at the time. Still, pass it did.

On the subject of working in the archives, French literary scholar and translator Alice Kaplan has written:

The archive owes its existence to the archivist's passion. An archive can be anyplace, but for the archive to be, there should be too much of it, too many papers to sift through. And there must also be pieces missing, something left to find. The best finds in the archives are the result of association and accident: chance in the archives favors the prepared mind. (Kaplan 1990: 103).

For the folklorist working in the Manx National Heritage Library with the papers of the collectors discussed here, there are indeed 'pieces missing,' and little room for chance remains, with much material beyond recovery. Folkloristics as a discipline creates its own archives through participants' collection of the tangible and intangible leavings of vernacular expressive culture. In the case of the Isle of Man, its archive is now a fragment of both what was once collected and of that culture itself. When researching and writing using these materials, one is conscious of a hidden voice, a voice perceived through the letters missing replies, their enclosures separated and lost; in the cracked and unplayable cylinders; and in the bindings that crack and spill the brittle pages of the few printed copies that now survive. One is ever writing in the presence of the absent, and one feels that there are always two accounts to be written: the first uses the materials that survive, and a shadow one relies on traces of what once was there.

\section{Competing Interests}

The author has no competing interests to declare.

\section{References}

Brady, Erika. 1999. A Spiral Way: How the Phonograph Changed Ethnography. University Press of Mississippi: Jackson.

Broadwood, Lucy E. 1925. "Preface [Songs from the Isle of Man (Part ii)]." Journal of the Folk-Song Society, 7(29): v.

Broderick, George [as "Shorys y Creayrie"]. n.d. 1983. "Recording Native Manx Speech." For a Celtic Future: A Tribute to Alan Heusaff, Cathal Ó. Luain (ed.), 308-20. Dublin: The Celtic League.

\footnotetext{
${ }^{38}$ It is in the possession of Manx National Heritage, inventory number IOMMM 1954-6335.

${ }^{39}$ Letter from Mona Douglas to Sophia Morrison, 25 October 1916, MS 09495, box 1.
} 
Clayton, Martin. 1996. "Ethnographic Wax Cylinders at the British Library National Sound Archives: A Brief History and Description of the Collection." British Journal of Ethnomusicology, 5: 67-92. DOI: https:// doi.org/10.1080/09681229608567248

Cubbon, William. 1935. "Dr John Clague's Collection of Folk-tunes." Journal of the Manx Museum, 3(44): 51a.

Gruber, Jacob W. 1970. "Ethnographic Salvage and the Shaping of Anthropology." American Anthropologist, 72(6): 1289-99. DOI: https://doi.org/10.1525/aa.1970.72.6.02a00040

H. M. Government. 1903. Census-1901: Islands in the British Seas. Cd. 1473. London: HMSO.

Kaplan, Alice Yaeger. 1990. "Working in the Archives." Yale French Studies, 77: 103-16. DOI: https://doi. org/10.2307/2930149

Kneen, J. J. 1925. "The Secretary's Report." 26th Annual Meeting held in the Town Hall, Douglas, on Saturday, Nov. 14th, 1925, 2-7. n.p.: Manx Language Society.

Kovács, Sándor. 1993. "The Ethnomusicologist." The Bartók Companion. Malcolm Gillies (ed.), 51-63. London: Faber and Faber.

Lechleitner, Gerda, and Ulla Remmer (eds.). 2003. The Collections of Rudolf Trebitsch: Celtic RecordingsIreland, Wales, Brittany, Isle of Man, and Scotland (1907-09). Series 5/2. Vienna: Österreichische Akademie der Wissenschaften.

List, George. 1958a. "A Short History of the Cylinder Phonograph [Part 1]." The Folklore and Folk Music Archivist, 1(2): [3].

List, George. 1958b. "A Short History of the Cylinder Phonograph [Part 2]." The Folklore and Folk Music Archivist, 1(3): [3].

List, George. 1958c. "The Reproduction of Cylinder Recordings [Part 1]." The Folklore and Folk Music Archivist 1(4): [2-3].

Miller, Stephen. 1993. "A.W. Moore: An Interim Checklist of Writings on Manx Folkways." Manx Notes: Folkways and Language, 10: 1-2.

Miller, Stephen. 2017. "The Manx Language Society (2): First Annual Report (1899)." Manx Notes: Folkways and Language, 283: 1-6.

Morrison, Sophia. 1905. "The Secretary's Report." Annual Meeting, 3-7. n.p.: Manx Language Society.

Morrison, Sophia. 1906. "Secretary's Report." Annual Meeting of the Manx Language Society, held in the Librarian's Room, Public Library, Douglas, on Thursday, November 22, 1906, 4-7. n.p.: Manx Language Society.

Myers, Charles S. 1907. "The Ethnological Study of Music. Appendix: The Manipulation of the Phonograph." Anthropological Essays presented to Edward Burnett Tylor, Northcote W. Thomas (ed.), 249-53. Oxford: Clarendon Press.

Quayle, J. E. 1937. "Manx Music." Proceedings of the Isle of Man Natural History and Antiquarian Society, 4(2): 240-50.

Rehding, Alexander. 2005. "Wax Cylinder Revolutions." The Musical Quarterly, 88(1): 123-60. DOI: https:// doi.org/10.1093/musqtl/gdi004.

Remmer, Ulla. 2003. "Rudolf Trebitsch and the Celtic Languages." The Collections of Rudolf Trebitsch: Celtic Recordings-Ireland, Wales, Brittany, Isle of Man, and Scotland (1907-09), Gerda Lechleitner, and Ulla Remmer, (eds.), 16 col. b-23 col. a. Series 5/2. Sound Documents from the Phonogrammarchiv of the Austrian Academy of Sciences: The Complete Historical Collections 1899-1950. Vienna: Österreichische Akademie der Wissenschaften.

Roeder, Charles. 1902. "Letter to the Editor." Isle of Man Examiner, April 26: 6a.

Savage, Canon Ernest B. 1905. "The President's Address." Annual Meeting, 1-3. n.p.: Manx Language Society.

Trebitsch, Rudolf. 1909. "Phonographische Aufnahmen der Welschen Sprache in Wales, der Manxschen Sprache auf der Insel Man, der Gälischen Sprache in Schottland und eines Musikinstrumentes in Schottland." Anzeiger der Kaiserlichen Akademie der Wissenschaften (Philosophisch-Historische Klasse), xlvi: $156-80$.

Yn Cheshaght Ghailckagh. 1905. "Balance Sheet from Hollantide 1904, to Hollantide, 1905." Annual Meeting, 1905. n.p.: Manx Language Society, 7.

Yn Cheshaght Ghailckagh. 1906. "Balance Sheet from Hollantide, 1905, to Hollantide, 1906." Annual Meeting of the Manx Language Society, held in the Librarian's Room, Public Library, Douglas, on Thursday, November 22, 1906, 3-4. n.p.: Manx Language Society.

Yn Cheshaght Ghailckagh. 1908, 3. "Balance Sheet." Annual Meeting of the Manx Language Society, held in Empire House, Promenade, Douglas, on Tuesday, March 24th, 1908, 3. n.p.: Manx Language Society. 
Yn Cheshaght Ghailckagh. 1909a. "The Balance Sheet." Annual Meeting of the Manx Language Society, held in Empire House, Central Promenade, Douglas, on Tuesday, March 23th, 1909, 3. n.p.: Manx Language Society.

Yn Cheshaght Ghailckagh. 1909b. Annual Meeting of the Manx Language Society, held in Empire House, Central Promenade, Douglas, on Tuesday, March 23th, 1909. n.p.: Manx Language Society.

\section{Manuscripts}

Manx National Heritage Library (Douglas, Isle of Man).

First Series

MS 221 A. A.W. Moore, Manx 'Odds \& Ends'.

MS 448/1-3 A. Dr John Clague Collection.

MS 449 B. Dr John Clague Collection.

MS 450/1-24 A. Notebooks compiled by Dr John Clague.

MS 1086 C. Letters from Sophia Morrison to J.J. Kneen (1904-14).

MS 1185 A. Letters from Rev. John Kewley to G.W. Wood (1911-17).

MS 1277 A. Letters from T.E. Brown to A.W. Moore (1892-97).

MS 1513 B. Letters from Sophia Morrison to J.J. Kneen (1908-15).

MS 5606 A. Letter from John Nelson to William Cubbon (28 November 1906).

New Series

MS 09495, Sophia Morrison Papers, Boxes 1, 2, 3, 4, 5, 6, 7.

MS 09702, Deemster J.F. Gill Papers, Box 2.

Photographic Archive

File Persons, Gill I.

Scrapbooks

J48-13XF

Yn Cheshaght Ghailckagh (Thie ny Gaelgey, St Jude's, Isle of Man)

Minute Book [1899-1913].

Manchester City Archives (Manchester, England)

M277/12/1-65. Scrapbook compiled by Karl Roeder.

In Family Hands

C.I. Paton, Personal Diary (1905-49).

How to cite this article: Miller, Stephen. 2018. 'Print is Much Safer than MS': The Fate of Folklore and Folk Song Collections in the Isle of Man. KULA: knowledge creation, dissemination, and preservation studies 2(1): 6. DOI: https://doi.org/10.5334/kula.26

Submitted: 21 February $2018 \quad$ Accepted: 19 May $2018 \quad$ Published: 29 November 2018

Copyright: (c) 2018 The Author(s). This is an open-access article distributed under the terms of the Creative Commons Attribution 4.0 International License (CC-BY 4.0), which permits unrestricted use, distribution, and reproduction in any medium, provided the original author and source are credited. See http://creativecommons.org/ licenses/by/4.0\%.

$|\mathrm{u}|$ 